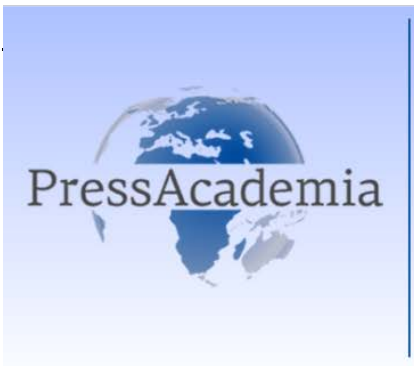

Press Academia Procedía

Global Business Research Congress (GBRC), May 26-27, 2016, Istanbul, Turkey.

\title{
AN EVALUATION ON LOGISTIC VILLAGE MARKETING AND THE LOGISTIC POTENTIAL OF VILLAGES IN TURKEY
}

\section{DOI: 10.17261/Pressacademia.2016118647}

\author{
Husniye Ors ${ }^{1}$, Toghrul Mammadov ${ }^{2}$ \\ ${ }^{1}$ Gazi Üniversitesi, husnive@gazi.edu.tr \\ ${ }^{2}$ Gazi Üniversitesi, tugrulcavansir@gmail.com
}

\begin{abstract}
Logistic villages, in terms of their role in world trade, provide large revenues to the national economy. In particular, bearing in mind the new trends in global trade, logistic villages in terms of becoming global logistics centers, expansion of national exports and in the economic development of the point they have reached, are very important from the point of Turkey. By considering the effects of logistics in global trade, the creation and development of the concept of a logistic village and its application in the world, logistic villages for Turkey have been analyzed from secondary data sources. The research, within the context of the marketing of a logistic village and bearing in mind the effect of Turkey on global trade strategies as well as considering existing applications, global developments and in particular today's economic and political developments, the priority structuring of logistic village and connection centers, especially of Kars and Erzurum provinces - due to their presence in the intersection of the cargo transport route of Asia and Europe - will be a distinctive opportunity in the medium- and long-run and in the continuing structuring and planned logistic villages through new cost-benefit analysis within world trade and political conjuncture which has revealed that advantaged logistic villages should commence their activities.
\end{abstract}

Keywords: Logistic villages, international marketing, foreign trade , international trade JEL Codes: M30, M38

\section{LOJISTIK KÖY PAZARLAMASI ve LOJISTIK KÖYLERINTÜRKIYE'DEKI POTANSIYELINE ILIŞKIN BIR DEĞERLEME}

\section{ÖZET}

Lojistik köyler, dünya ticaretindeki rolleri itibariyle ülke ekonomileri için oldukça büyük getiriler sağlamaktadır. Özellikle küresel ticaretteki yeni trendler göz önünde bulundurulduğunda, küresel lojistik merkez olma, ülke ihracatııın gelișmesi, bulunduğu noktaları ekonomik yönden geliştirmesi bakımından lojistik köyler Türkiye açısından da çok önemlidir. Çalışmada küresel ticarette lojistiğin etkisi, lojistik köy kavramının oluşumu, gelişimi ve dünyadaki uygulamaları dikkate alınarak, Türkiye açısından lojistik köyler ikincil veri kaynakları ile incelenmiştir. Araştırma, lojistik köy pazarlaması bağlamında Türkiye'nin küresel ticaret stratejilerine etkisi de göz önünde bulundurularak, mevcut uygulamalar, dünyadaki gelişmeler ve özellikle günümüz ekonomik ve politik gelişmeler dikkate alındığında, enerji hatlarının ve Asya Avrupa yük taşıma rotasının kesişim noktasında bulunmaları nedeniyle öncelikle Kars ve Erzurum illerinde lojistik köy ve bağlantılı merkezlerin ivedilikle yapılanmasının orta ve uzun dönemde ayıııı bir fırsat olduğunu, yapılanması devam eden ve planlanan lojistik köylerin değişmeye devam eden dünya ticaret ve politik konjonktüründe maliyet-fayda analizlerinin yeniden yapılarak, avantajlı olanların faaliyete başlaması gerektiğini ortaya koymuştur.

Anahtar Kelimeler: Lojistik köyler, uluslararası pazarlama, dış ticaret JEL Kodları: M30, M38 


\section{GiRiş}

Küreselleşme ile beraber dünya ticaretinde yaşanan dönüşüm ve yeni oluşumların etkileri, lojistik sektörü üzerinde de görülmektedir. Bu bağlamda lojistik sektörünün ve lojistik faaliyetlerinin önemi her geçen gün daha da artmaktadır. Lojistik kavramı günümüzde kaynak planlaması, küreselleşme, tedarik zinciri yönetimi ve optimizasyonu gibi kavramlarla anılır olmuştur. Küreselleşen dünya ticareti ve yeni ekonomi anlayışı ile lojistik faaliyetleri farklı bir yapıya kavuşturmuştur. Sektör ve uygulamalarda karşılaşılan bahse konu farklılıklar lojistik çeşitlerine ve işlemlerine yansımış ve bu işlemlerin mümkün olan en az maliyetlerle, hızlı, kaliteli, ölçek ekonomisinden yararlanır vaziyette ve birbiriyle bütünleşmiş olarak gerçekleştirilmesinin gerekliliği hususu bir anlamda lojistik köylerin oluşumuna neden olmuştur. Gümrük işleyişinin her ülkede farklı olmasından dolayı, lojistik köyler için farklı ülkelerde "Lojistik Üs", "Transport Center", "Logistical Park", "Lojistik Merkez" gibi farklı isimler kullanılmaktadır.

Lojistik köylerin ortaya çıkış nedeninin artan dünya ticaretinin her geçen yıl büyüyen hacmi ve günümüz dünya ticaretinin Asya eğilimli olması beraber incelendiğinde, Türkiye'de lojistik köylerin mevcudiyetinin önemi aşikardır. Son yıllarda Avrasya ve Karadeniz bölgesinin demir ve kara yolları büyük önem taşımaya başlamıştır. İpek yolunun bir ucunda gelişen ekonomisiyle Çin, diğer ucunda ise Avrupa Birliği ülkeleri durmaktadır. Türkiye'nin bu yolun ortasında bulunması, üç tarafının denizlerle çevrili olması ve diğer jeopolitik avantajları lojistik bir üs haline gelmesi için yeterli değildir. Bu avantajlara ek olarak Türkiye'nin lojistik faaliyet potansiyelleri ortaya çıkarılmalı ve bu potansiyeller doğru şekilde pazarlanmalıdır. Bu bağlamda çalışmanın amacı; lojistik köylerin dünya ticaretindeki önemini ortaya koyarak lojistik köy farkındalığını arttırmak, Türkiye'nin lojistik köy potansiyelini araştırmak ve bunların daha etkin çalışması için önerilerde bulunmaktır. Çalışma ikincil veri kaynaklarına dayalı kuramsal bir özellik taşımaktadır.

\section{KÜRESELLEŞEN DÜNYA TICARETINDE LOJISTIĞiN ÖNEMi}

Dünya ticaretinin küreselleşmesi sonucunda sermaye, üretim ve tüketim gibi faktörler de küreselleşmiş ve dünya ticareti 2015 yılı itibariyle 41 Trilyon dolar gibi devasa bir hacme ulaşmıştır. Ülkelerarası ticaretin oluşmasının sebebi bir anlamda doğal şartlarla da ilgilidir. Bir ülkede yerli üretim kapsamında bazı ürünlerin hiç olmaması veya az olması farklı ülkelerden bu ürünlerin teminini zorunlu kılmaktadır. İhtiyaç duyulan yeraltı ve yerüstü kaynakların karşılanması için ticaret ve nakliyenin (lojistiğin) yapııması gerekmektedir. Dünya ticaretindeki genel görünüme bakılınca, Asya ekonomilerinin küresel ticaretteki paylarını düzenli olarak arttırdıkları gözlemlenmektedir. Asya'nın ikinci dünya savaşı sonrasında \%14 olan dünya ticareti içindeki payı sürekli bir büyüme eğilimi izleyerek bugün \%30 oranını geçmiş durumdadır. Bu ülkeler arasında özellikle Çin'in durumu dikkat çekmektedir. Bu değişen ticari koşullarda Asya'da üretilen ürünlerin Avrupa'ya en hızlı, en güvenli ve en düşük maliyette sevk edilmesi gerekmektedir ki bu durum "ipek yolu” olarak adlandırılan güzergahın ortasında yer alan Türkiye için büyük avantaj anlamına gelmektedir (Kara vd., 2009).

Küresel ticarette daha fazla yer edinmek ve dış ticaret rakamlarını yükseltmek için kurum ve işletmelerin rekabet üstünlüğü sağlayacak avantajlar yakalaması gerekmektedir. Günümüz ticaretinde işletmeler iki temel faktör olan üretim ve pazarlamanın, pazarlama kısmına daha çok önem vermektedirler. Pazarlamanın temel amacının üretilen mamul veya hizmet için doğru ürünü, doğru yerde, doğru zamanda, doğru satıcıya, doğru fiyatla, doğru müşteriye ulaştırmak olduğu dikkate alındığında, lojistiğin literatürde "Seven R's" olarak bilinen yedi doğrusunun (doğru ürünü, doğru şartlarda, doğru yerde, doğru miktarda, doğru zamanda, doğru tüketiciye, doğru fiyatla ulaştırılması) pazarlamanın hedefleriyle aynı olduğu görülmekte ve lojistik ile pazarlama ilişkisi daha iyi anlaşılmaktadır (Çekerol, 2015). Lojistiğin pazarlama fonksiyonları açısından çok etkin bir yere sahip olduğu bilinmektedir. Küresel pazarlardaki değişiklikler, işletmeler arasında rekabet avantajı elde etmek için yapılan faaliyetlere de yansımaktadır. Uluslar arası pazarlarda faaliyet gösteren işletmeler için rekabet stratejilerinden olan dağıtım kanallarını etkinleştirmek, lojistik maliyetlerini düşürmek ve küresel lojistik kanallarının verimliliğini artırmak ayrıca önem taşımaktadır.

DTÖ verilerine göre dış ticaretin coğrafi bölge ve kıtalara göre dağılımı incelendiğinde Avrupa, Asya ve Kuzey Amerika ülkelerinin dünya ticaretinin \%80'inden fazlasını gerçekleştirdiğini görmekteyiz. Yoğunlaşmanın olduğu bölgelerde lojistik faaliyeti, özellikle denizyolu taşımacılığını arttırmaktadır. Lojistik ticari malların dış pazarlara 
kısa sürede ve ucuz maliyet ile ulaştırılması bakımından en az gümrük mevzuatları kadar önemli bir konudur. Taşıma maliyetlerinin düşmesi nedeniyle ihraç malların fiyatlarının da rekabet edebilir seviyeye çekilmesi çok önemli bir avantaj sağlamaktadır. Günümüzde sanayileşmiş ülkelerde lojistik ve diğer altyapı unsurlarının gelişmiş olması, taşıma maliyetleri ve malların kısa sürede pazara sunulmasında önemli katkı sağlamaktadır. Lojistik altyapının tamamlanmış olması ülkelerin kalkınmasında da önemli rol oynamaktadır (Özdemir vd., 2015). Küresel pazarlarda sürekli oyuncu olmak isteyen işletmelerin rekabetçi üstünlük sağlamalarının yolu iyi hazırlanmış lojistik stratejilerine sahip olmalarından geçmektedir. Bu anlamda hem işletmelerin hem de ülkelerin lojistik merkez ve lojistik değer yaklaşımıyla konuyu ele almaları gerekmektedir (Şahin vd., 2015).

\section{LOJISTIK KÖY KAVRAMI}

Küreselleşme ve buna bağlı olarak artan ticaret hacmi ülke ve bölge ekonomilerine olumlu etkiler yapmakta, satışları artırmakta ve iş dünyasını canlandırıp dengelemektedir. Bu dinamik yapıda ağır taşıtların yaygın kullanılmasından dolayı hava kirliliği, trafik sıkışıklığı, bölgesel rekabet gibi olumsuz etkiler de doğmaktadır. Artan ticaret hacmi beraberinde gelen lojistik hareketliliğin şehir merkezlerine yaptığı baskılar, lojistik merkezlerin doğma nedeni olarak da görülmektedir (Demiroğlu ve Eleren, 2014).

Kavram olarak lojistik merkez ilk kez ABD’de sanayinin gelişmesi ile kullanılmaya başlanmıştır. Japonya'da bu kavramın, trafik sıkışıkığını önleme, enerji ve işgücü maliyetlerini düşürme ve çevresel giderleri azaltma gibi faaliyetler için kullanıldığı da bilinmektedir. Sonraki süreçte Batı Avrupa'da da görülmeye başlayan uygulamanın ilk örnekleri Fransa'da oluşturulmuştur (Paris bölgesi alanı; Garanor ve Sogoris-Rungis). Amerika Birleşik Devletlerinde lojistik merkez/lojistik üs kavramına iç liman (inland port) denmektedir. Burada lojistik merkez yapılanması esasen iki amaçla uygulanmıştır: Fazla büyümemiş eski sanayi alanlarının canlandırıması ve yük amaçlı planlanan birim gelişimi denen oluşumların kurulabilmesi. Lojistik faaliyetlerin yürütülebilmesi için özel olarak planlanmış ve kurulmuş alanlara lojistik merkez denilmektedir. Bir lojistik merkez farklı hizmet sağlayıcıları tarafından ticari olarak ulusal ve uluslar arası taşımacılık ile ilgili tüm lojistik faaliyetlerin gerçekleştirildiği bir bölgedir. Türkiye'de bu kavram "lojistik köy”, "yük köyü”, "lojistik üs" gibi terimlerle ifade edilmektedir (Şahin vd., 2015). Çeşitli ülkelerde çeşitli tanımlarla ifade edilen lojistik köyler, Türkiye'de bu uygulamanın planlayıcısı ve uygulayıcısı olan Türkiye Cumhuriyeti Devlet Demir Yolları (TCDD) tarafından; “lojistik ve taşımacılık şirketleri ile ilgili resmi kurumların içinde yer aldığı, her türlü ulaştırma moduna etkin bağlantıları olan, depolama, bakım-onarım, yükleme-boşaltma, elleçleme, tartı, yükleri bölme, birleştirme, paketleme, vb. faaliyetleri gerçekleştirme imkanları olan ve taşıma modları arasında düşük maliyetli, hızlı, güvenli aktarma alan ve donanımına sahip bölgeler" olarak tanımlanmıştır (http://www.tcdd.gov.tr).

Kavram olarak ülkeler bazında da "lojistik köy" için farklı tanımlamalar kullanılmaktadır. Almanya'da bu çeşit kümelenmelere 'lojistik köy', Japonya'da 'dağıtım parkı', İspanya'da ise 'lojistik platformları' denilmektedir. Dünyada kapasitesi en yüksek ve en çok bilinen lojistik merkezlere örnek olarak; ABD’de Memphis lojistik merkezi ve Fort Worth lojistik merkezi, Avrupa'da Zaragoza lojistik merkezi ve Almanya demiryolu hattı ile Hollanda'yı birleştiren Rotterdam Limanı lojistik merkezi örnek gösterilebilir. Singapur limanı çevresindeki lojistik kümelenme ve Panama kanalı lojistik merkezleri de bu bağlamda değerlendirilmektedir (Üzümcü, 2015).

Lojistik köylerin ana amaçları; taşıma araçlarının, lojistik zincirinin, iş gücü ve depo kullanımının optimizasyonu ile toplu taşıma ve personel maliyetlerinin minimize etmektir. Lojistik üsler iktisadi anlamda bölgenin kalkınmasına olumlu etki yapmakla beraber işletmelerin çevreye karşı daha duyarlı faaliyet göstermesini de sağlamaktadır. Sanayi - üretim merkezlerine, şehirlere, demiryolu hatlarına, hava limanlarına, karayolu hatlarına, limanlara yakınlık ve şehir trafiğini direk etkilememe lojistik köyler için aranan özelliklerdendir (Karadeniz ve Akpınar, 2011).

Lojistik merkezlerdeki çalışmalar sistem etkinliği sağlayarak yüksek kalite yakalama odaklı yapılmaktadır. Bu bağlamda tedarik zincirinin, taşıt kullanımının, depo kullanımının, işgücünün optimizasyonunun sağlandığı, toplam taşıma harcamalarının, toplam endüstriyel harcamaların, personel giderlerinin minimize edildiği ve bu şekilde toplam cirolarda artış hedeflendiği lojistik köylerin özellikleri aşağıdaki gibi sıralanabilir(Karadeniz ve Akpınar, 2011): 
- $\quad$ Coğrafi Konumu

- Karayolu, Denizyolu, Demiryolu, İç suyolu ve boru hatlarına bağlantıları

- Kombine taşımacılık altyapısı, intermodal ve multimodal terminaller

- $\quad$ Ticari odaklı ihracat, ithalat, transit ve gümrük rejimleri

- Bölge ülkelerine yakınlık

- Üretim - Sanayi merkezlerine yakınlık

- $\quad$ Tüketim Merkezlerine - Pazarlara yakınlık

- $\quad$ Standartlaştırılmış iş süreçleri

- $\quad$ Yasal çerçevede basitlik

- $\quad$ Illetişim ve bilgi teknolojilerinin gelişmiş altyapıya sahip olması

- $\quad$ Lojistik Köyün Saha genişliği (konteyner alanı, araç parkı, ofisler, depolar vs.)

- Gelişmiş Liman Altyapısı (Vinç, forklift vd. teknik donanımlar)

- $\quad$ Rıhtım Uzunluğu (Denizyolu)

- $\quad$ Pist Uzunluğu (Havayolu)

- $\quad$ Ro-Ro ve Yolcu terminalleri

- Transit taşımacılığa uygunluk

- $\quad$ İşletmelerin kullanabileceği modern ofisler

- $\quad$ Gümrük ve Müşavirlik birimleri

- $\quad$ Paketleme, ambalaj, elleçleme hizmetleri

- $\quad$ Dağıtım merkezleri

- $\quad$ Sigorta, Bankacılık ve Finans Hizmetleri veren kurumlar

- Soğutmalı depolar

- $\quad$ Silolar ve Kapalı depolar

- $\quad$ Tehlikeli madde depolama merkezleri

- $\quad$ Tersane bakım onarım ve servis birimleri

- Havayolu Kargo için faaliyet gösteren pist sayısı ve uzunlukları

- Havayolu taşımacılığı için gelişmiş yer hizmetleri

- Mesleki eğitimler, Lojistik Eğitim kurumlarının mevcudiyeti

- Uzmanlaşmış insan kaynağı

- $\quad$ Sosyal mekanların kalitesi (dinlenme, eğlence, konaklama)

Sayılan bu özelliklerin yanında lojistik köylerin, en az 250 hektar alana sahip olması, bir metropolün yakınında olması, karayolu ulaşımı ve demiryolu bağlantısının olması, iç suyoluna, çok türlü taşımacılık tesisine, liman ve havaalanlarına yakın olması, planlı imar modern ofis, depo ve binalara sahip olması ve bilgi teknolojileri altyapısının gelişmiş olması da önemli fiziksel özellikleridir (lojiblog.com). Lojistik köylerin ana amaçları; taşıma araçlarının, lojistik zincirinin, iş gücü ve depo kullanımının optimizasyonu ile toplu taşıma ve personel 
maliyetlerinin minimize etmektir. Lojistik üsler iktisadi anlamda bölgenin kalkınmasına olumlu etki yapmakla beraber işletmelerin çevreye karşı daha duyarlı faaliyet göstermesini de sağlamaktadır (Karadeniz ve Akpınar, 2011).

Ülkelere ve bölgelere göre değişiklik gösteriyor olsa da bir lojistik köydeki en önemli yapılar, özellikler ve burada verilen hizmetler genelde benzerlik teşkil etmektedir. Şöyle ki; lojistik köylerde en önemli yapılar genelde depolar ve multimodal/intermodal terminallerdir. Yüklerin ve verilen hizmetlerin çeşitliliğine bağlı olarak depo türleri de değişmektedir. Örneğin, koruma amaçlı depolar, lojistik depoları, karayolu - tren yolu aktarma depoları, soğutmalı depolar, dock depolar (yükseltilebilir yanaşma yerine sahip depo). Lojistik köylerde kurulu terminallerin ise intermodal, multimodal ve kombine taşımacılık faaliyetlerine ve aktarmalarına elverişli olması gerekmektedir. Bir lojistik köy projesinin temel özellikleri şunlardır; master plan, tek merkezden yönetim, kaliteli yerleşim, açık ve kapalı stok alanları ve yardımcı destek hizmetleri.

Lojistik köylerin sahip olması gereken hizmetleri şu şekilde özetlemek mümkündür: Farklı ölçülerde depolar ve tesisler, güvenlik hizmetleri, sağlık hizmetleri, hukuki hizmetler, toplu taşıma ile ulaşım, park alanı, otel, lokanta ve restoran, yakıt istasyonu, araç servis noktaları. Bu tarz hizmetler hem işletmelerin hem de yönetimin işini kolaylaştırmakta ve hizmet kalitesini olumlu yönde etkilemektedir (Europlatforms EEIG, 2004). Lojistik köyler, bünyesinde faaliyet gösteren işletmelerden bağımsız bir tüzel kişiliktir. Bu sebeple görev ve faaliyetleri de lojistik köy bünyesinde faaliyet gösteren işletmelerden farklıdır. Bu görevler aşağıda sıralandığı gibidir (Şahin vd., 2015):

- Altyapı gereksinimlerini belirleme (karayolu bağlantıları, demiryolu bağlantıları, limanlara bağlantılar)

-Lojistik köye ilişkin yapısal unsurları belirleme (posta, banka, sigorta hizmetleri, depolar, ofisler, intermodal terminaller, diğer servisler)

-Genel altyapı ve bütünleşik hizmetleri organize etme (lojistik köy yönetimi, tüm altyapıdan sorumludur)

-Lojistik köyün ticari, idari ve mali kontrolü

-Ortak alanların bakım ve korunması ve yönetimi

- Taşıyıcılara yer, işletmelere ofis ve depo kiralanması, depo ve ofislerin satılması, bu işlemlerle ilgili ticari ve pazarlama faaliyetlerini yürüterek yasal işlemlerin halledilmesi.

\subsection{Avrupa'da Lojistik Köyler}

2011 yılında $A B$ Komisyonu tarafından 10 yıllık ulaştırma politikalarını belirleyen esas belgelerden biri olan "Ulaştırma Beyaz Kitabı” yayınlanmıştır. Bu belge kapsamında küresel ticarette artış gösteren Asya faktörüne vurgu yapılmış ve değişen ticari dengelere bağlı olarak lojistikte de kaybedilen üstünlüğün geri kazanılması gerekliliği verilerle ortaya konulmuştur. Bu kapsamda lojistik ve ulaştırma konularında iki strateji belirlenmiştir; "akıllı uzmanlaşma ve kümelenme". Günümüzde hem Avrupa'da hem de başka coğrafyalarda hızla benimsenen kümelenme, Avrupa Birliği'nin 2020 yılına yönelik “Ufuklar 2020" stratejisinin unsurları arasında yer alan akıllı uzmanlaşma ve kaynakların etkin kullanımı kavramlarını içermektedir. Rekabet öncesi işbirliği-güçbirliği modeli olarak bilinen bu yöntemde "Üçlü Sarmal" olarak anılan ve sanayi, devlet ve üniversite arasında gerçekleştirilen bir işbirliği ile tüm tarafların kendi uzmanlık alanları ve olanakları ile yaptıkları işbölümünde kümeye maksimum katkı sağlamaktadır. Lojistikle ilgili çeşitli faaliyetleri aynı mekanda bir araya getirme de bir çeşit kümelenme olarak kabul edilmektedir. Bu tür merkezlerde devlet tarafı düzenleme, yasa ve yönetmelik boyutunu; üniversite, araştırma kurumları ve danışmanlar tarafı araştırma boyutunu; hizmet sağlayıcı sektör işletmeleri ise talep sunma boyutunu temsil etmektedirler (TOBB, 2014).

Avrupa'daki lojistik merkezler estetik açıdan zengin ve ana ulaşım ağlarına yakın ve intermodal taşımaya elverişli eski sanayi alanlarının kullanılması esasına dayanılarak tasarlanmıştır (Peker vd., 2011). Avrupa genelinde on ülkede ( İtalya, İspanya, Fransa, Portekiz, Almanya, Danimarka, Yunanistan, Macaristan, Ukrayna ve Lüksemburg ) bulunan lojistik üsler Avrupa Lojistik Merkezler Birliği (Europlatforms) üyesidir (http://www.europlatforms.eu). 
Avrupa'nın, özellikle lojistik sektörünü kalkınma stratejileri kapsamında ele alan Valonya, Kuzey Ren Vestfalya vb. bölgelerinde, lojistik paydaşları ilgili bölgenin rekabet gücünü arttıııı projeler etrafında bir araya getiren yaklaşımlar hızla yaygınlaşmaktadır. Avrupa'da oluşturulan ve aşağıda detaylı örnekleri verilen bölgesel lojistik kümelerin kurulmasında aşağıda sıralanan temel maddeler dikkate alınmıştır (Türkiye Ulaştırma ve Lojistik Meclisi Sektör Raporu 2014);

- Bölgelere göre uzmanlaşma merkezlerinin belirlenmesi,

- Belirlenen bu merkezlere özgü fazla işlenmemiş konuların ortaya çıkartılması,

- Bir biriyle bağlantılı sektörler ile ilişki ağları oluşturulması,

- Bu alanlara göre, araştırma kuruluşu ve üniversitelerin tekrardan yapılanması,

- Devletin ve ilgili kamu kurumlarının bu alanlara yönelik destekleyici mekanizmalar oluşturması,

- Bu ihtisas alanlarında bölgelerin uluslar arası rekabet üstünlüğü elde etmesine yönelik faaliyetler yapılması.

Kümelenme anlayışı çerçevesinde, İspanya'da "Lojistik Platformlar", Almanya'da "Lojistik Köyler", Fransa'da "Rekabetçilik Kutupları" ya da "Yetkinlik Merkezleri" olarak adlandırılan yapılar kurulmuştur. Avrupa'daki lojistik merkezlerin bağlı bulunduğu üst kuruluş Europlatforms (The European Logistics Platforms Association)'un Ocak 2004 Raporu'na göre Avrupa'daki lojistik köyler üç temel fikir üzerine kurulmuştur:

-Bölgesel planlama yanında altyapının rasyonalize edilmesi,

-Taşıma Kalitesi,

-Intermodal taşımacııı̆ın geliştirilmesi

Europlatforms Ekim 2015 Kurumsal tanıtım sunumundaki verilere göre, Avrupa'daki Lojistik Köylerin (Transport \& Logistic Centre) dağııımı aşağıdaki gibidir:

\section{Almanya}

$6132 \mathrm{Ha}$ alan üzerine kurulu 35 merkez mevcuttur. Bu merkezlerin birçoğu Kamu Özel Ortaklığı çerçevesinde kurulmuştur (Public-Private Parthnership). Bunlardan 21'i Deutsche GVZ-GesellschaftmbH tarafından yönetilmektedir. Tüm merkezlerin iç sulara ray bağlantısı mevcuttur ve tüm modlarda hizmet vermektedir ( karayolu, demiryolu, deniz yolu, nehir, havayolu).

ispanya

3726 Ha alan üzerine kurulu 33 merkez mevcuttur. Bu merkezlerin birçoğu A.C.T.E. (Asociación de Centros de Transporte en España) tarafından yönetilmektedir. İç suyolu hariç diğer modlarda hizmet verilmektedir, ki iç suyolu Sevilla hariç i̇spanya için uygun bir taşıma modu değildir. Merkezlerin çoğu birbirine ray bağlantısı ile bağlıdır, hava ve deniz bağlantısı da diğer Avrupa ülkeleri ile kıyasla iyi durumdadır.

\section{Fransa}

Euralogistic: Fransa'nın kuzey bölgesini kapsayan çatı lojistik merkez kuruluşu (Region of Nord-Pas de Calais) ve Sogaris Lojistik merkezi ve diğerleri ile beraber Fransa'da toplam 26 Lojistik köy bulunuyor. Bunlar 2756 Ha alan ürerine kurulmuştur ve neredeyse tümü birbirine ray bağlantısına sahiptir. Tüm taşıma modları uygulanmakla

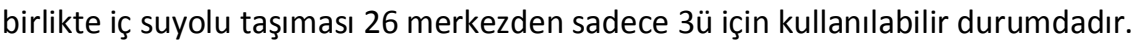

\section{İtalya}

3460 Ha alan üzerine kurulu 21 Lojistik merkezin kurulduğu İalya'da lojistik köyler arası denizyolu ve hava yolu bağlantısı çok kısıtlıdır. U.I.R.'in (L’Unione Interporti Riuniti) en etkin kuruluş olduğu bu merkezler arasında iç suyolu bağlantısı mevcut değildir. 


\begin{abstract}
Hollanda
"Association of theDutch T\&L Companies" ve "Association of Dutch Goods Transportation Companies" Hollanda'daki en önemli iki çatı kuruluştur. $999 \mathrm{Ha}$ alan üzerine kurulu 15 Lojistik merkezi mevcuttur. Intermodal taşımacılık gelişmiş seviyededir ve ayrı ayrı merkezler için geçerli olmak üzere tüm taşıma modlarında hizmet verilmektedir.
\end{abstract}

\title{
Çek Cumhuriyeti
}

Çek Lojistik Derneği, ülke içindeki tüm lojistik merkezlere eğitim desteği vermekte ve bilgi alışverişinde aracı ve yardımcı rol üstlenmektedir. $496 \mathrm{Ha}$ alan üzerine kurulu 11 lojistik köyde karayolu ve demiryolu arası intermodalite mevcuttur. İç suyolu ve havayolu bağlantıları ise çok kısıtlıdır. Çek cumhuriyet'inde Lojistik Köyler Kamu Özel ortaklığı kapsamında Devlet tarafından finanse edilmektedir.

\section{Danimarka}

F.D.T. "Danimarkalı Nakliye ve Lojistik Merkezleri Derneği” Danimarka'daki lojistik köyleri destekleyen ticari bir kuruluştur. 1.195 Ha arazi üzerine kurulu 7 merkezin bulunduğu Danimarka'da Çek Cumhuriyetinde olduğu gibi denizyolu bağlantıları zayıftır ve indermodalite karayolu-demiryolu şeklindedir. Kamu Özel Ortaklığı çerçevesinde Devletin Lojistik merkezlere finansal destek sağlaması Danimarka'da da görülmektedir ve "Nordic Lojistik Merkezi" buna verilecek en iyi örneklerdendir.

\section{İsveç}

S.I.F.A. (Swedish International Freight Association) ve S.I.L.F. (Swedish National Association of Purchasing \& Logistics) İsveç'deki en bilinen iki organizasyondur. Karayolu - demiryolu - denizyolu bağlantılarının mevcut olduğu $445 \mathrm{Ha}$ arazi üzerine kurulu 10 lojistik köy bulunmaktadır. Merkezler tarafından iç suyolu ve hava yolu taşıma hizmeti verilmemektedir.

\section{Birleşik Krallık}

F.T.A. (Freight Transport Association), U.K.W.A. (United Kingdom Warehousing Association) ve C.I.L.T. (Chartered Institute of Logistics and Transport in the UK) Birleşik Krallıktaki en önemli üç oluşumdur. Büyük bir bölümünün özel sektörün elinde olduğu $858 \mathrm{Ha}$ alana kurulu 9 lojistik merkez mevcuttur. Hava yolu ve Deniz yolu taşıma hizmetinin sınırlı olduğu iç suyolu taşıma hizmetinin ise hiç verilmediği görülmektedir. İntermodal bağlantı karayolu - demiryolu şeklinde karşımıza çıkmaktadır.

Bahsedilen ülkelerin dışında, Belçika'da 997 Ha arazi üzerine kurulu 7, Macaristan'da 216 Ha arazi üzerine kurulu 7, Portekiz'de $393 \mathrm{Ha}$ arazi üzerine kurulu 6, Polonya'da 346 Ha arazi üzerine kurulu 6, Slovakya'da 89 Ha arazi üzerine kurulu 6, Avusturya'da 867 Ha arazi üzerine kurulu 5, Finlandiya'da 330 Ha arazi üzerine kurulu 5, Hırvatistan'da $465 \mathrm{Ha}$ arazi üzerine kurulu 4, Lüksemburg'da $124 \mathrm{Ha}$ arazi üzerine kurulu 4, İrlanda Cumhuriyeti'nde $55 \mathrm{Ha}$ arazi üzerine kurulu 4, Litvanya'da $592 \mathrm{Ha}$ arazi üzerine kurulu 3, Estonya'da $340 \mathrm{Ha}$ arazi üzerine kurulu 3, Kıbrıs'ta 95 Ha arazi üzerine kurulu 3, Yunanistan'da $263 \mathrm{Ha}$ arazi üzerine kurulu 2, Slovenya'da $158 \mathrm{Ha}$ arazi üzerine kurulu 2, Letonya'da $105 \mathrm{Ha}$ arazi üzerine kurulu 2, Malta'da 89 Ha arazi üzerine kurulu 2, Romanya'da $250 \mathrm{Ha}$ arazi üzerine kurulu 1, Bulgaristan'da $70 \mathrm{Ha}$ arazi üzerine kurulu 1 olmak üzere, $25891 \mathrm{Ha}$ arazi üzerine kurulu toplam 240 lojistik köy faaliyet göstermektedir.

Ticari hacimleri ile ilgili bir örnek teşkil etmesi sebebiyle İspanya'nın Zaragoza kentindeki Plaza Lojistik merkezine ( Plaza Logistica Zaragoza) ait bazı rakamlar incelemeğe değer niteliktedir. Bu merkez 1200 hektarlık alanı ile Avrupa'nın en büyüğüdür. Merkez 20 milyon müşterisiyle, lojistik aktarma merkezlerine, demiryolu hatlarına ve dünyanın en büyük kargo uçaklarının bulunduğu havaalanına sahiptir. İspanya GSMH'sının \%60'ını, bu 20 milyon müşteri oluşturmaktadır (Şahin vd., 2015).

\subsection{Türkiye'de Lojistik Köyler}

Asya ve Avrupa kıtalarını birbirine bağlayan coğrafi konumu ve Doğu ile Batı arasındaki doğal bir köprü vazifesi görmesi ile Türkiye "Asyalaşan” küresel ticarette önemli bir yer tutmaktadır. Stratejik konumu itibariyle Türkiye, dünya ticaret hacminin yarısının gerçekleştiği birden fazla pazara kolay erişim sağlamaktadır. DTÖ ve T.C 
Ekonomi Bakanlığı verilerine göre Türkiye’nin 2015 yılı itibariyle toplam dünya ticareti içinde \%1 olan payı 2025 yılına kadar \%1.5 seviyesine çıkarılarak \%50'lik bir ilerleme sağlanacaktır. Şöyle ki "2016-2018 Orta Vadeli Program" ve "2023 ìhracat Stratejisi" çerçevesinde, Türkiye'nin ihracatının 2016 yılında 150 milyar, 2017 yılında 170 milyar, 2018 yılında 193.5 milyar, 2023 yılında ise 500 milyar dolar seviyesine ulaşması beklenmektedir (T.C Ekonomi Bakanlığı, Ekonomik Görünüm, Aralık 2015).

2023 vizyonu ve hedefi çerçevesinde lojistik, ulaştırma ve taşımacılık alanlarında da bir dizi proje ve uzun vadeli plan uygulamaya konmuştur. Bu bağlamda büyük ölçekli yeni lojistik merkezileri, 36.500 km bölünmüş yol, 7.500 km otoyol, 2019 yılında Boğaz'da bir denizaltı tüp geçit ve 3. köprü, Çanakkale Boğazı'nda köprü, 10.000 km hızlı tren demiryolu, 4.000 km ilave demiryolu, yılda 500 km demiryolunun yenilenmesi, demiryollarının özel sektöre açılması, terminal ve istasyonların yenilenmesi, hızlı trenlere yönelik yeni terminallerin inşası, ülkemizi Kafkaslar'a, Ortadoğu ve Kuzey Afrika'ya bağlayacak yeni demiryolu projelerinin desteklenmesi, ülkemizdeki ana limanların demiryollarına bağlanması ve bu gibi büyük projeler mevcuttur (MÜSiAD Lojistik sektör raporu, 2013).

Dünya Bankası tarafından ilki 2007 ikincisi 2010 sonuncusu 2014 yılında yayınlanan Küresel Lojistik Performans Endeksi, lojistik alanında en güncel ve en kapsamlı ölçüt kabul edilmektedir. Gümrüklerin etkinliği, ticaret ve taşımacılık altyapısının lojistik açısından kalitesi, uluslar arası sevkiyat düzenlemenin kolaylığı ve maliyet avantajı, sevkiyatların takibi ve izlenmesi ve sevkiyatın alıcıya zamanında ulaşabilmesi gibi kriterlere göre $1-5$ arası puanlama sistemiyle, lojistik profesyonellerine yönelik anket uygulanarak yapılan araştırmanın sonuçlarına göre; Türkiye 3.50 puanla 33. sırada listede kendine yer bulmuştur. Birinci sıradaki Almanya'nın puanı 4.12dir. En düşük skorlarımız uluslar arası sevkiyat düzenlemenin kolaylığı ve maliyet avantajı (3.18 puan) ve gümrüklerin etkinliği (3.23 puan) konularındadır (Ipi.worldbank.org).

Türkiye'de lojistik köy planlaması ve uygulamasını Ulaştırma Bakanlığı'nın öncülüğünde TCDD yürütmektedir. TCDD’nin planlamasına göre lojistik merkezlerin İstanbul (Halkalı), Kocaeli (Köseköy), Eskişehir (Hasanbey), Balıkesir (Gökköy), Kayseri (Boğazköprü), Samsun (Gelemen), Denizli (Kalkık), Mersin (Yenice), Erzurum (Palandöken), Konya (Kayacık), İstanbul (Yeşilbayır), Bozüyük (Bilecik), Maraş (Türkoğlu), Şırnak (Habur), Bitlis (Tatvan), İzmir (Kemalpaşa), Mardin, Uşak, Sivas ve Kars olmak üzere taşıma potansiyeli yoğun bölgelere ve organize sanayi bölgelerinin bulunduğu merkezlere kurulması kararlaştırılmıştır. Projelere başlanmadan önce Avrupa'da özellikle de Almanya'da bulunan merkezler uzmanlar tarafından ziyaret edilmiş ve burada incelemelerde bulunulmuştur. Yukarıda da bahsettiğimiz üzere Avrupa'daki oluşumlar kümelenme yaklaşımı ile planlanıp uygulandığından, bir dizi maliyet avantajı yaratmaktadır. Avrupa'daki lojistik merkezlerin demiryolunu etkin bir biçimde kullandığı gözlemlendiğinden dolayı, Türkiye'deki projeler de demiryollarının daha etkin kullanılması fikriyle planlanmıştır. Bu sayede ülkemizdeki demiryolu faaliyetleri de artacak ve iyileşecektir (Sezen ve Gürsev, 2014).

TCDD’nin yanı sıra İstanbul Büyükşehir Belediyesi'nin de (IBB) Hadımköy ve Tuzla'da olmak üzere lojistik köy projeleri mevcuttur. Bu projelerin tamamlanmasıyla İstanbul içinde tır deposu ve antrepo olarak dağınık halde bulunan alanların merkeze taşınması sağlanacaktır. 2015 yılı verilerine göre planlamada toplam 20 adet olan lojistik merkez, ondokuzu TCDD ve biri AYGM tarafından yürütülen projeler kademeli olarak devreye alınmış ve 2016 yılı sonunda 6 merkezin daha devreye alınması beklenmektedir. Açılmış merkezler ise Samsun (Gelemen), İstanbul (Halkalı), Eskişehir (Hasanbey), Denizli (Kaklık), Kocaeli (Köseköy), Balıkesir (Gökköy) ve Uşak'tadır (http://lojiblog.com/iki-yilda-7-lojistik-koy-faaliyete-basladi-6-ise-yolda/).

Yapılan araştırmada açıldığı belirtilen lojistik merkezlerin hiçbiri ile ilgili detaylı bilgiye ulaşılamamıştır. Ayrıca bazı basın ve yayın organlarında lojistik köylerin bazıları hakkında iş sağlığı ve güvenliği, ulaşım, sosyal tesis, güvenlik, kalifiye personel vb., alanlarda eksiklik olduğu da dikkat çekicidir. (http://www.ufukulastirmasen.org.tr). Lojistik merkezlerin, detay ve istatistiklere ulaşılabilecek web siteleri bulunmadığı gibi açılışı gerçekleştirilenlerin de tam anlamıyla faaliyette olmadığı ve etap-etap işletmeye alındığı görülmektedir. Bu köylerin yer seçim kriterleri aşağıdaki gibidir:

- $\quad$ Organize Sanayi Bölgeleri yakınında ve ya içinde olması,

- Farklı taşıma modlarının aynı anda kullanılmasının mümkün olması, 
- Demiryolu hattı yakınında olmalı,

- Karayolu ve mümkünse deniz ve havayolu bağlantılarının olması,

- Taşıma potansiyeli olması,

- $\quad$ Fizibilite etüdünden uygundur kararı çıkması,

- Bölgesel sanayi geliştirme planları içinde olması,

- $\quad$ Arazi altyapısı teknik olarak gelişime müsait olması.

Yine TCDD raporlarına göre, lojistik merkezde konteynır boşaltma, stok ve yükleme alanları, gümrük alanları, tır parkları, otoparklar, müşteri ofisleri, banka, restoran, otel gibi hizmet alanları, bakım onarım ve yıkama tesisleri, akaryakıt istasyonları, antrepolar, tren kabul ve sevk yolları bulunmaktadır. Söz konusu alanların şehirlerde kalmış olan yük ve depo merkezleri lojistik merkezlere taşınarak, bu sahaların tekrar kente kazandırılmasının sağlanması düşünülmektedir (http://www.utikad.org.tr/haberler/?id=10633).

Türkiye'de yapımı tamamlanan lojistik merkezlerin faaliyet sonuçları ile ilgili bilgi almak ve yapımı devam eden projelerle ilgili istatistiki bilgi edinmek oldukça güçtür. Örneğin Türkiye'de Lojistik Köy faaliyetlerini yürüten TCDD önceki yıla ait yıllık raporunda bu konuya hiç değinmemiştir. Bu nedenle lojistik merkezler konusunda yapılmış çalışmaların çoğu ikincil veri kaynaklarından elde edilen bilgiler ışığında ve genel öneri niteliğindedir.

\section{SONUÇ VE ÖNERILER}

Türkiye'de lojistik merkez planlamasının ağıılıklı olarak demir yollarının genel durumu ve fiziksel koşullar temel alınarak yapıldığı görülmektedir. Hem faaliyette olan hem planlanan lojistik köylerin yer seçimi incelendiğinde Mersin'in uluslar arası limanlara açılan deniz yolu olması ve serbest bölgesi sebebiyle, Konya ve Bilecik / Bozüyük'ün ise Anadolu'nun içerilerine ulaşım bakımından önemli olduğu anlaşılmaktadır. Bozüyük merkezinin Eskişehir'le yakın olması ilk anda uygunsuz bir seçim gibi görülse de sadece uluslar arası değil iç bağlantıların da önemi göz önünde bulundurulduğunda, Marmara bölgesi ile i̇ç Anadolu arasında köprü görevi gördüğü anlaşılmaktadır. Bursa ilinin lojistik merkez olması ise bağlantı yollarının uygun olmasından ziyade sanayi merkezi olmasıyla ilgilidir. Bu anlamda Eskişehir'in uluslar arası lojistik hatlarına bağlanması için EskişehirKonya-Mersin güzergahı düşünülebilir. Planlanmış olan bir diğer merkez de Erzurum lojistik köyüdür. Gelecekteki İpek Demiryolu Projesi ile Kars üzerinden Nahçivan'a bağlanması ve daha önemli konuma gelmesi muhtemeldir. Türkiye bu sayede Erzurum üzerinden Azerbaycan, İran ve Gürcistan'a etkin tren yolu bağlantısı sağlayacaktır.

Genel olarak liman kentlerindeki merkezleri uluslar arası bağlantılı diğer bölgelerdeki merkezleri ise iç bağlantılı olarak niteleyebiliriz. Liman bağlantılı merkezler ve batı bölgesindeki sanayi bölgeleri yakınındaki merkezler ayrı tutulmak kaydıyla, bazı lojistik merkezlerin son yılların küresel ekonomik ve politik olayların da etkisiyle orta vadede işlevsiz kalabileceği söylenebilir. Son dönemdeki Türkiye Rusya krizi, İran'a uygulanan ambargonun kalkması, İran'ın yeniden Batı ile entegrasyonuve enerji fiyatlarındaki gelişmeler, önümüzdeki yıllarda dünya ticaretinin ve buna bağlı olarak da lojistikteki gelişmelerin seyrini değiştireceği izlenimi vermektedir. Türkiye’nin bu şartlar altında dünya ticaretinin çekim noktası haline gelmiş olan Asya'ya odaklanması gerekmektedir. Bunun için en uygun alternatifin Hazar olduğu söylenebilir. Hazar bölgesi Asya Pasifik'le bağlantı için hayati önem taşımaktadır. Türkiye'nin doğusunda yer alan Hazar koridoru ülkeleri lojistik üs ve transit ülke olmak için çalışmalar yürütmektedirler. Çin'den Azerbaycan'ın başkenti Bakü'ye uzanan 4 bin kilometrelik demiryolunun yapımı hali hazırda bitmiş durumdadır. 838 kilometrelik Bakü-Tiflis-Kars hattı da Azerbaycan ve Gürcistan tarafından çoğunlukla bitirilmiş ve Türkiye tarafındaki 76 kilometrelik bölümünün bitmesi beklenmektedir. Bakü-Tiflis-Kars hattının diğer lojistik köy ve enerji transferi konularından daha öncelikli olduğu söylenebilir. Avrupa Birliği'nin komşuluk politikası çerçevesinde, Azerbaycan ve Gürcistan'la ivedi bir ilişki sürdürdüğü açıkça görülmektedir. Türkiye'nin bu fırsatı avantaja dönüştürmemesi durumunda, bu hat Gürcistan'dan, Karadeniz üzerinden Romanya'ya ve oradan da Avrupa'nın diğer ülkelerine ulaşabilir. Yukarıda bahsedilen sebepler ve Orta Asya taşımacılık rotası, Kars ilinde kurulması planlanan Lojistik Köyün en önemlilerden biri olduğunu ortaya koymaktadır. Kars Lojistik Merkezinin önemi aşağıdaki gibi özetlenebilir: 
Kars şehri oldukça önemli ticaret ve enerji rotalarının kesişim noktasında yer almaktadır. Türkiye'nin Kafkasya ve Orta Asya'ya açılan kapısı olarak nitelendirilen şehir, Bakü-Tiflis-Ceyhan petrol boru hattı, Bakü-TiflisErzurum, İran-Ankara ve TANAP Projesi doğal gaz boru hatları gibi projelerin güzergahında bulunmaktadır. Ayrıca Kars, Demir İpekyolu olarak adlandırılan Bakü-Tiflis-Kars ve proje aşamasında olan Kars-lğdır-Nahcivanİran Demiryolu Hatları ile de yakından ilgilidir. Lojistik Üs olma yolunda çok büyük avantajlara sahip olan Kars'ın bu projelerin faaliyete geçmesiyle "Doğu'nun Merkezi" konumuna gelmesi büyük olasılıktır. Ayrıca demiryolu ile Ankara ve İstanbul'a bağlanan Kars, Bakü-Tiflis-Kars, Trabzon-Kars ve Kars-lğdır-Nahcivan-Iran demir yolları ve Sivas-Kars Hızlı Tren Hattı ile daha önemli bir konuma sahip olacaktır. Mevcut yüksek kapasiteli hava alanı, yakınında bulunan Aktaş, Türkgözü, Dilucu ve Gürbulak sınır kapıları Kars'ın önemini daha da artırmaktadır. Kars şehrine kurulacak lojistik köyün sadece ülke için değil bölge için de bir merkez olacağı aşikardır çünkü 2015 yılı sonunda Azerbaycan'da faaliyete başlayan $400 \mathrm{Ha}$ alan üzerine kurulu Bakü Uluslar arası Deniz Ticareti Limanı, 25 milyon ton yük, 1 milyon TEU konteynır rakamlarına ulaşacaktır. Hem liman hem demiryolu projesinin Azerbaycan tarafından yapılandırılma şekli de Kars'ın önemini ortaya koymaktadır. Buna göre; Bakü-Tiflis-Kars projesinin hayata geçirilmesi ve Boğazda demiryolunun inşası, Trans-Avrupa ve Trans-Asya demiryolu şebekelerinin birleşmesine, yük ve yolcuların direkt olarak Azerbaycan, Gürcistan ve Türkiye arazisinden geçmekle Avrupa ve Asya'ya çıkarılmasını temin etmekle birlikte, bölgedeki üç ülkenin transit potansiyelinin artmasına, Avrupa'yaentegrasyon sürecinin hızlanmasına, Avrupa Komşuluk ilişkileri çerçevesinde işbirliğinin de artmasına ve Azerbaycan'ın uluslararası iktisadi ilişkilerinin gelişmesine hizmet edecektir. Gelecekte Avrupa ve Asya ülkelerine özgü yüklerin demiryoluna yönlendirilmesi her iki istikamette intermodal ve konteynır taşımalarının hacmini yükseltecektir. Azerbaycan Ulaştırma Bakanlığı’nın öngörüsüne göre projenin bitiminden sonra Çin'den Avrupa'ya taşınacak olan bir yükün ulaştırma süresi yarıya düşecek ve 12 gün civarında olacaktır. Projenin altıncı senesinde 10 milyon ton yük taşıyacağı tahmin edilmektedir. Bakü-Tiflis-Kars tren yolunun tamamlanmasıyla birlikte Avrupa ile Orta Asya arasındaki yük taşımalarının tümünün demir yoluna kaydırılması planlanmaktadır. Çin'den Avrupa'ya kesintisiz demiryolu lojistiği projesi hayata geçtiğinde, 2034 yllında 16 milyon 500 bin ton yük ile 1 milyon 500 bin yolcu taşınması öngörülmektedir. Kars'ın lojistik merkez olmasının özellikle Azerbaycan ve Gürcistan yatııımcıları gibi dış yatırımcıları bölgeye çekeceği öngörülmektedir.

Yukarıda yer seçimleri ile ilgili bazı noktalara değinilmiştir fakat sadece yer seçimi lojistik köyleri değerlendirmek için ölçüt değildir. İnşaatı devam eden batıda, Bozüyük/Bilecik ve doğuda Palandöken/Erzurum ve Mardin Lojistik köyleri diğer merkez üslere destek amaçı planlanmış izlenimi vermektedir. Ulaştırma bakanının açıklamasında da belirttiği gibi lojistik köyler ihracatçılara lojistik maliyetlerini azaltma konusunda avantaj sağlayacağı varsayımıyla organize sanayi bölgelerine yakın planlanmıştır. Bir diğer ölçüt de giderek taşımacılığın demiryoluna aktarılması ve kombine taşımacılı̆ı̆n önünün açılmasıdır. Sadece organize sanayi bölgelerine yakınlık ve demiryolu bağlantısı bu planlanan merkezlerin tam anlamıyla lojistik köy işlevini yerine getireceği anlamını taşımamaktadır. Örneğin Eskişehir (Hasanbey) Lojistik Merkezi lojistik binası, kısım şefliği binası, yol müdürlüğü mekanik atölye binası, trafik ve sosyal tesisler binası, idari bina, lokobakım atölye binası, vagon atölye binası, yüksek rampalı hangar binası, gözetleme kulesi, nizamiye binası ve beton kaplama sahası ile daha çok gelişmiş bir tren garını andırmaktadır. Projelerin genelde demiryoluna yönelme, demiryollarını iyileştirme amaçlı olduğu Balıkesir lojistik köy projesinin isminden de anlaşılmaktadır (Tren Garı Kentsel Dönüşümü ve TCDD Gökköy Lojistik Köyü Projesi) ancak diğer taşıma türlerinin önemi ve bağlantı hatlarının maliyet düşürücü etkileri de göz önünde bulundurulmalıdır. Örneğin; Denizli'de kurulan Kalkık lojistik merkezi (daha çok üretilen mermer ve tekstil ürünlerinin Ege'deki limanlara taşınması için tasarlanmış) üzerinden nakliye yapmak, elleçleme ve organize sanayi bölgesinden demiryolu hatlı lojistik merkeze yapılan kara nakliyesi masrafları eklendiği zaman direk kara nakliyesinden daha maliyetli olacağı aşikardır.

Bu bilgiler ışığında eksikliklerimizin altyapısal ve fiziki özelliklerden ziyade, etkin ve verimli tedarik zinciri yönetimine sahip olmamamızdan kaynaklandı̆̆ı görülmektedir. Günümüz lojistik sektörü giderek e-lojistik olarak adlandırılan, bilgi işlem ve teknolojilerinin tüm aşamalarda yaygın kullanıldığı modern bir çehreye bürünmektedir. Çeşitli kuruluşların yaptığı araştırmaların sonuçlarına istinaden, önümüzdeki 20 yılda lojistik sektörünün kapsam ve anlamında köklü değişiklikler olacağı öngörülmektedir. Bu öngörüler ışığında aşağıdaki öneriler geliştirilmiştir: 
-2015 yılından sonra ulaştırma altyapısında reklam geliri kavramı ortaya çıkacaktır. Günümüzde stadyumlara isim vermek için büyük bütçeler ayıran firmalar vardır ve yakın gelecekte limanlara, otoyollara, demir yolu istasyonlarına da isim reklamı vermek mümkün olacaktır. Japonya'da bazı demir yolları bu uygulamayı başlatmıştır. Türkiye'de Lojistik Köyler kapsamında yenilenen demiryolu istasyonları da bu uygulamayı hayata geçirebilir.

-2020 yılından sonra limanlar ile lojistik merkezler arasında konteynır taşıyan konveyör bantların kurulması planlanmaktadır. Türkiye'de şehir içinde kalmış limanlar bu teknolojiden faydalanarak büyük avantaj elde edebilirler.

-2020 yılında hızlı tren hatlarının yük taşıması da yapacağı öngörülmektedir. Bilindiği üzere Türkiye'de YHT projeleri hızı bir şekilde devam etmektedir. Bu konu lojistik avantajı kapsamında ele alınmalı ve bitmemiş projelerin planlaması ilerde yük taşımacılığı da yapacak şekilde değiştirilmelidir.

-2030 yılına kadar sadece bilişim ve iletişim alanında değil, lojistiğin tüm süreçlerini kapsayan farklı teknolojik gelişmeler beklenmektedir. Büyük bölümü şimdiden icat edilmiş ama ticari hayata entegre edilmemiş bu yöntem ve teknolojileri (karbondioksit absorbe eden maddeler, katlanabilir konteynırlar, yolları yenileyen bakteriler, hava koşullarına göre transforme olan gemi ve uçaklar, kendini yenileyen bio-beton) takip etmek ve hala proje ve yapım aşamasında olan lojistik köyleri oluştururken, birkaç sene sonra atıl durumda kalabilecek hiçbir teşebbüse yatırım yapılmaması önerilir.

-Küçük hacimli kargo taşımacılığında yer altı tüneller vasıtasıyla raylı sistemle yük (2 standart europalet ebadında) taşınacağı öngörülmektedir. Dağıtım ve bağlantı merkezleri planlanırken bu gibi konuların da göz önünde bulundurulması Türkiye açısından oldukça önemli olduğu dikkate alınmalıdır.

-Açıklanan tüm fiziksel ve teknolojik altyapıdan ve teknolojiden bağımsız olarak lojistik faaliyetlerin nihayetinde insanlar tarafından gerçekleştirildiği göz ardı edilmemeli, sektörün şu an sıkıntısını çektiği kalifiye eleman eksikliği giderilmelidir. Bunun için üniversite-lojistik köy işbirliği projeleri geliştirilebilir, lojistik merkezlere sürekli eğitim kurumları tahsis edilebilir, lojistik alanında eğitim veren kurumların sayısı çoğaltılabilir ve bu kurumlardaki öğrencilerin lojistik merkezlerde süreçleri yerinde görmesine olanak sağlayacak projeler geliştirilebilir.

-Hedef üç kıtanın lojistik üssü konumuna gelmek ise, bu hedef doğrultusunda sadece demir yollarına değil, denizlerle çevrili bir ülke olmanın avantajı da kullanarak deniz taşımacılığı bağlamında lojistik üsler ve bağlantılarına da gereken özen gösterilmeli ve planlanmalar bu doğrultuda yapılmalıdır. Önemli liman kentlerinde bu konuda çalışmalar yapılmaktadır. Konu ile ilgili birçok bilimsel çalışmada önerilen Trabzon'a lojistik üs kurulması da yeniden değerlendirilebilir.

-Yaklaşık 500 milyon dolar maliyetli bu lojistik köy projelerinin tamamlandıktan sonra etkin bir şekilde ekonomik katkı sağlaması için, ana arter olan "demir ipek yolu” olarak adlandırılan hattın deniz yolu bağlantıları da titizlikle planlanmalı ve organize edilmelidir. Lojistik köyler projelerinin kamu özel ortaklığı çerçevesinde yürütüldüğü ve hem Rusya hem de Almanya merkezli işletmelerin bu lojistik köylerin işletmeciliğine talip olduğu bilinmektedir. Kısa vadede bazılarında bu merkezler yabancıların işletmeciliğine teslim edilse bile, uzun dönemde hem teknolojiyi üretme ve kullanma hem de kalifiye eleman yetiştirme bağlamında uygulamaya dayalı eğitime önem verilmesi ve yönetim ve işletmecilik yetkisinin yerel işletmelere verilmesi amaca daha uygun olacaktır.

-2000'li yıllardan itibaren lojistik literatürüne girmiş bir başka konu da, tedarik zinciri faaliyetlerini yerine getirirken, yaşadığımız dünyayı da korumak anlamına gelen "yeşil lojistik" kavramıdır. Yeşil lojistik kapsamında artık işletme ve organizasyonlar çevreye en az zararı vererek lojistik faaliyetlerini gerçekleştirme çabası içindedirler. Küresel Lojistik Köy olma yolunda Türkiye de bu gerçeği göz ardı etmemeli, Avrupa Birliği entegrasyonu kapsamında zorunluluk haline gelmeden önce planlamayı hem rekabet avantajı elde etmek hem de gelecek nesillere daha yaşanabilir bir dünya bırakmak için "Yeşil Lojistik" yaklaşımıyla olgunlaştırılması önerilir. 


\section{KAYNAKÇA}

Çekerol, G.S. 2015, “Lojistik Yönetimi”, Eskişehir: T.C. Anadolu Üniversitesi Yayını No:2823, 2.Baskı:88-151

Demiroğlu, Ş. Ve Eleren, A. 2014, “Küresel Lojistik Köyleri ve Türkiye'de Kurulması Planlanan Lojistik Köy Bölgelerinin ÇKKV Yöntemleriyle Belirlenmesi", Dumlupınar Üniversitesi Sosyal Bilimler Dergisi, 42:, s.189-202.

Europlatforms European Association of Transport \&Logistics Centres, Corporate Presentation Final - October 2015.

http://europlatforms.eu, Erişim Tarihi: 20.02.2016

http://lojiblog.com, Erişim Tarihi: 21.02.2016

http://lojiblog.com/iki-yilda-7-lojistik-koy-faaliyete-basladi-6-ise-yolda/, Erişim Tarihi: 20.02.2016

http:///pi.worldbank.org, Erişim Tarihi: 21.02.2016

http://www.tcdd.gov.tr, Erişim Tarihi: 21.02.2016

http://www.ufukulastirmasen.org.tr, Erişim Tarihi: 10.02.2016

http://www.utikad.org.tr/haberler/?id=10633, Erişim Tarihi: 16.02.2016

Kara, M., Tayfur, L., Basık, H. 2009, "Küresel Ticarette Lojistik Üslerin Önemi ve Türkiye”, Mustafa Kemal Üniversitesi Sosyal Bilimler Enstitüsü Dergisi, 6(11), s. 69-84.

Karadeniz, V. ve Akpınar, E. 2011, "Türkiye'de Lojistik Köy Uygulamaları ve Yeni Bir Lojistik Köy Önerisi”, Marmara Coğrafya Dergisi, (23), s. 49-71.

Logıstıcs centres directıons for use, A report by Europlatforms EEIG, January 2004

MÜSIAD Lojistik sektör raporu 2013, ISBN 978-605-4383-33-7, İstanbul, Aralık 2013.

Özdemir, A., Çatalbaş, N., Kaya, E., Turan, G., Kuyucak, Ş.F., Nalçakan, M. 2015, “Lojistik IIlkeleri”, Eskişehir: T.C. Anadolu Üniversitesi Yayını No:2517, 6.Baskı:3-29

Sezen, B. ve Gürsev, S. 2014, “Türkiye'de Kurulması Planlanan Lojistik Merkezler Hakkında Bir Analiz Çalışması”, Marmara Üniversitesi Öneri Dergisi, 11(42), s. 105-126.

Şahin, G., Sipahioğlu, A., Kamışlı, Ö.Z., Ertek,G., Aba,B., Büyükozan, G. 2015, “Uluslararası Lojistik”, Eskişehir: T.C. Anadolu Üniversitesi Yayını No:2625, 3.Baskı.

T.C. Ekonomi Bakanlığı, Ekonomik görünüm Aralık 2015, Güncelleme Tarihi: 25/12/2015

Türkiye Ulaştırma ve Lojistik Meclisi Sektör Raporu 2014, (2015), TOBB Yayın Sıra No: 2015/260.

Üzümcü, A. 2015, "Kars Lojistik Merkezinin (KLM) TRA2 Bölgesinin Kalkınması Ve Kars Ekonomisi Açısından Önemi: Bir iktisadi Analiz", Kafkas Üniversitesi iktisadi ve Idari Bilimler Fakültesi KAÜ iiBF Dergisi, 6(10), s. 191-222. 